\title{
Feeding selectivity of Holothuria atra in different microhabitat in Panjang Island, Jepara (Java, Indonesia)
}

\author{
RETNO HARTATI ${ }^{1, \vartheta}$, MUHAMMAD ZAINURI ${ }^{2}$, AMBARIYANTO AMBARIYANTO ${ }^{1}$, \\ WIDIANINGSIH WIDIANINGSIH ${ }^{1}$ \\ ${ }^{1}$ Department of Marine Science, Faculty of Fisheries and Marine Science, Universitas Diponegoro. Jl. Prof. H. Soedarto, S.H., Tembalang, Semarang \\ 50275, Central Java, Indonesia. Tel.: +62-24-7474698, Fax.: +62-24-7474698, `email: retnohartati.undip@yahoo.com \\ ${ }^{2}$ Department of Oceanography, Faculty of Fisheries and Marine Science, Universitas Diponegoro. Jl. Prof. H. Soedarto, S.H., Tembalang, Semarang \\ 50275, Central Java, Indonesia
}

Manuscript received: 17 March 2020. Revision accepted: 26 April 2020.

\begin{abstract}
Hartati R, Zainuri M, Ambariyanto A, Widianingsih W. 2020. Feeding selectivity of Holothuria atra in different microhabitat in Panjang Island, Jepara (Java, Indonesia). Biodiversitas 21: 2233-2239. Particle selectivity by deposit feeder sea cucumber Holothuria atra was an important concept in its feeding ecology. This species utilized the organic matter that coated sediment and detrital particles as food. Thus, particle size, organic matter, and microalgal biomass had been proposed as variables food resources along which niche separation could occur in optimal foraging strategy. This study was conducted in five microhabitats of different coverage of seagrass bed (P1-P4) up to the rubble area (P5) over a tidally variable depth range of 0,5-5m in Panjang island, Jepara. Twenty samples of sea cucumber $H$. atra were taken from defined microhabitat, along with samples of sediment underneath the sea cucumber. Granulometry of the particles ingested by sea cucumbers, total organic matter, and microphytobenthic biomass (as chlorophyll-a) found throughout their digestive tract (alimentary canal) and in the sediments was analyzed. Comparison of the contents and the rates of organic matter assimilation of the digestive tract with those of the microhabitat sediment were carried out. The results showed that $H$. atra fed on sediment underneath their body and it was revealed that there were strong ( $p=0.833-0.876)$ to very strong $(p=0.945)$ positive relationship between grain size in the sediment and in their alimentary canal which showed their feeding selectivity of the sediment. $\mathrm{H}$. atra also found to have efficiency in feeding by taking advantage of the high TOM content and high abundance of microphytobenthic organisms (presented as chlorophyll-a) in their natural microhabitats.
\end{abstract}

Keywords: Chlorophyll-a, organic matter, sea cucumber, sediment characteristic

\section{INTRODUCTION}

Holothuria atra was one the most common black Holothurian and the most frequently encountered sea cucumber in Indonesia (Setyastuti 2015), which was commonly known as lollyfish. These common shallowwater species were rarely found in depths of more than 20 $\mathrm{m}$, and mostly on inner and outer reefs flats and back reefs or shallow coastal lagoons. It was abundant on sandymuddy grounds with rubble or coral patches and in seagrass beds. Inshore shallow-water populations were denser, composed of smaller individuals, while in deeper or outer reef populations, the individuals were more scattered with larger individuals (Dissanayake and Stefansson 2012). This species was found in a variety of habitats over a broad range (Liu et al., 2013). In Panjang Island, Jepara, H. atra was found on the seabed, in shallow waters on reefs and sand flats and in seagrass meadows at depths of up to 10 meters (Hartati et al. 2019a,b). It also occupied pools of water from a few centimeters to about one-half meter deep at low tide, and was occasionally entirely exposed. It usually covered itself with a coating of light coral sand held in place by tube feet, although occasionally, it was naked and black.

Naturally, the abundance of sea cucumber was very strongly affected by the availability of natural food in the habitat (Hartati et al. 2017). The complex and heterogeneous habitat could provide many diverse food sources for sea cucumbers. $H$. atra, just like $H$. arguinensis, might prefer a more complex habitat that had different microhabitats across small areas, which was able to support varied population density with different size individuals (Domínguez-Godino and GonzálezWangüemert 2020). Kashio et al. (2016) also stated that sea cucumber showed changing their microhabitat and activity level seasonally and when they found a suitable one, their feeding process continued.

Holothuria atra was an omnivore, sifting through the sediment with its tentacles and feeding on detritus and other organic matter (Setyastuti 2014; Hartati et al. 2017). It ingested sand at the same time and digested the biofilm on the sand grains before ejecting them through its anus. Particle selectivity by deposit feeders, such as $H$. atra was an important concept in its feeding ecology. These species utilized the organic matter that coated sediment and detrital particles as food. Thus, particle size, organic matter, and microalgal biomass had been proposed as variables food resources along which niche separation could occur in optimal foraging strategy. Feeding activity and its relation with feeding selectivity had been discussed in deposit feeders such as $H$. sanctori (Navarro et al. 2013), Apostichopus japonicus (Sun et al. 2015) and H. scabra 
(Lee et al. 2018), and generally related to their habitat. However, there was little information regarding feeding selectivity of $H$. atra in their microhabitats. This issue was interesting since coastal areas typically encompassed a range of habitats with different compositions and abundance of organisms (Dissanayake and Stefansson 2012), which might influence the way food was distributed for holothurian (Sauchyn et al. 2011). The present works were aimed to analyze the feeding activity of $H$. atra in different seagrass coverage as microhabitats and their relation in feeding selectivity.

\section{MATERIALS AND METHODS}

\section{Study area}

The study was conducted in five microhabitats of different coverage of Seagrass bed (P1-P4) up to the rubble area (P5) over a tidally variable depth range of 0.5-5.0 m (Table 1) of Panjang Island, Jepara (Figure 1). There were Cymodocea serrulata, Enhalus acoroides, Thalassia hemprichii, Halodule uninervis, Syringodium isoetifolium in those seagrass bed but $C$. serrulata was found as dominated species. $C$. serrulata or commonly named as Serrated ribbon seagrass which is considered common and widespread throughout tropical Indo-West Pacific usually dominant in muddy reef tops. The characteristic $C$. serrulata was long ribbon-like leaves with blunt, rounded tips that have serrations (these are sometimes very tiny). The leaf scars around the upright stem are not continuous. It has thick rhizomes (underground stems). The leaf sheaths around the leaf were flattened, sometimes seen with reddish band (Wagey, 2017). The different microhabitats based on their coverage of seagrass were observed for their population of sea cucumber in habitat in those locations.

Along with $H$. atra samples collection, water quality parameters such as temperature, salinity, $\mathrm{pH}$, and dissolved oxygen (DO) were measured in situ using U-50 series Multi-parameter water quality checker. The analyses of total organic matter, chlorophyll-a, and grain size of sediment were conducted in Marine Biology Laboratory, Department of Marine Sciences, Faculty of Fisheries and Marine Science, Diponegoro University, Semarang, Central Java, Indonesia

Table 1. Geographical position of sampling stations at Panjang Island, Jepara District, Central Java Province, Indonesia

\begin{tabular}{llllll}
\hline Coordinate & \multicolumn{1}{c}{ P-1 } & \multicolumn{1}{c}{ P-2 } & \multicolumn{1}{c}{ P-3 } & \multicolumn{1}{c}{ P-4 } & \multicolumn{1}{c}{ P-5 } \\
\hline Longitude & $06^{\circ} 34^{\prime} 34,3^{\prime \prime}$ & $06^{\circ} 34^{\prime} 34^{\prime \prime}$ & $06^{\circ} 34^{\prime} 31,4^{\prime \prime}$ & $06^{\circ} 34^{\prime} 32,7^{\prime \prime}$ & $06^{\circ} 34^{\prime} 33,9^{\prime \prime}$ \\
Latitude & $110^{\circ} 37^{\prime} 53,5^{\prime \prime}$ & $110^{\circ} 37^{\prime} 54,7^{\prime \prime}$ & $110^{\circ} 37^{\prime} 54,4^{\prime \prime}$ & $110^{\circ} 37^{\prime} 53,3^{\prime \prime}$ & $110^{\circ} 37^{\prime} 52,4^{\prime \prime}$ \\
Seagrass coverage & $56^{\prime}$ & $40 \%$ & $25 \%$ & $12 \%$ & $0 \%$ \\
Dominant species & C. serrulata & C. serrulata & C. serrulata & C. serrulata & Rubble \\
\hline
\end{tabular}
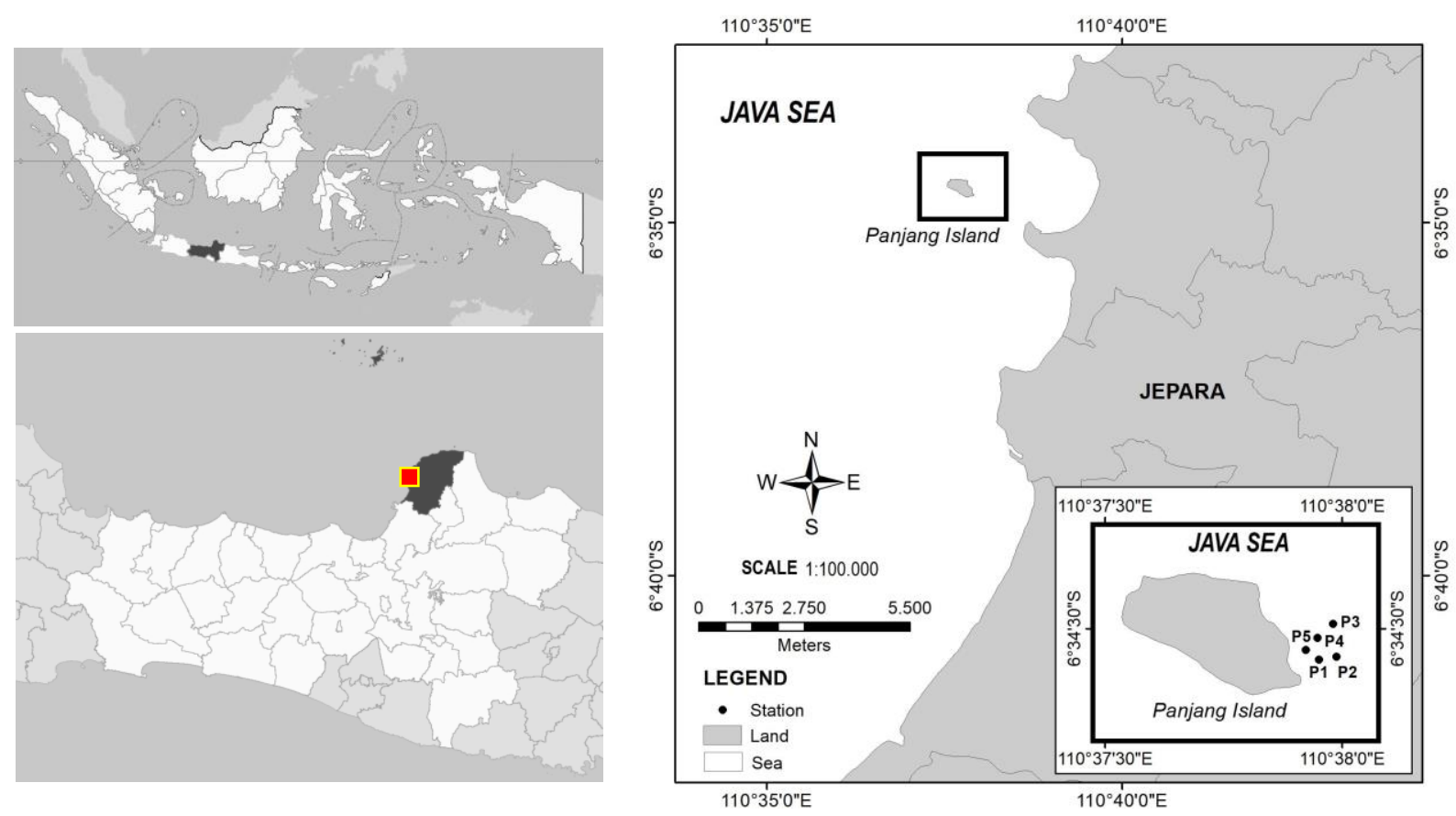

Figure 1. Map of sampling stations of Panjang Island, Jepara District, Central Java Province, Indonesia 


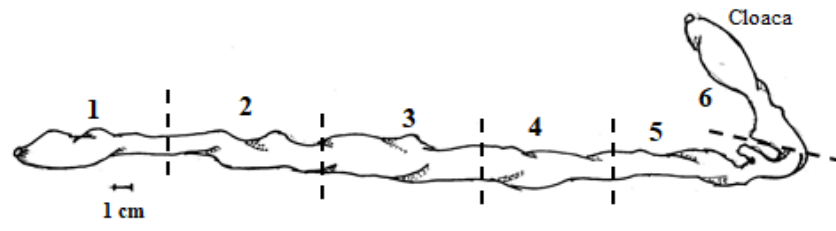

Figure 2. The alimentary canal of Holothuria atra. Note: 1. Pharynx, 2. Esophagus, 3. Stomach, 4. Descending intestine 1, 5. Ascending intestine, 6. Descending intestine 2 and Cloaca)

\section{Procedures}

Twenty samples of sea cucumber $H$. atra (range weight of 7,7-106,4 g) were taken from five different seagrass coverage of $H$. atra microhabitat as described in Table 1. Samples of $H$. atra were placed in plastic buckets and immediately transported to Marine Station Laboratory of Marine Science Departement, Faculty of Fisheries and Marine Science-Diponegoro University. In laboratory, they were measured their weight and the sea cucumbers were immediately placed inside plastic bags and into iced seawater to slow down their metabolism and to stop the activity of the digestive enzymes. Four sea cucumber were dissected, and the alimentary canals were extracted, laid out, measured from mouth to anus and divided into six equal parts by length according to Kusumadewi and Hartati (2003) and Hartati et al. (2016), i.e., pharynx, esophagus, stomach, descending intestine 1, ascending intestine, descending intestine 2 and cloaca (Figure 2). From each part of the alimentary canal, the digesta (i.e., mixture of sediment and digestive juices inside) was completely removed, and put in a ziplock sample plastic bag for further analysis. Ten grams of the digesta were taken out immediately for the subsequent measurement of the TOM and Chlorofill-a to determine their changes due to digestive processes sequentially along the gut. The digesta of 16 sea cucumber samples from each microhabitat (stations) were pooled and measured for their grain sizes.

Sediment of the surface substrate (up to $3 \mathrm{~cm}$ depth) underneath the sea cucumber and seawater were taken from each station. Grain size of sediment was also analyzed. A regression analysis was applied in order to establish the relationship between sediment characteristic (grain size) of upper layer sediment of each microhabitat and digesta of every part of alimentary canals.

Total Organic Matter (TOM) and chlorophyll-a content in seawater and sediment samples were measured to determine the microphytobenthic biomass. Total organic matter analysis was done using the 'ash method' (Wang et al. 2011). The samples of sediment were dried in the oven at $60^{\circ} \mathrm{C}$ for $72 \mathrm{~h}$ and then $12 \mathrm{~g}$ were taken and burned at $450^{\circ} \mathrm{C}$ for five $\mathrm{h}$ in a combustion chamber. Samples were then cooled in a desiccator, and the final weight was recorded. TOM content was then calculated as a loss on ignition. The chlorophyll-a of sediment was extracted with a standard ethanol extractions and pre- and postacidification measurements. A Perkin-Elmer Lambda 3BUV/VIS spectrophotometer with a $1 \mathrm{~nm}$ spectral bandwidth and optically matched $4 \mathrm{~cm}$ micro-cuvettes are used in the present work (de Jonge et al. 2012).

\section{RESULTS AND DISCUSSION}

\section{Results}

Holothuria atra in this present work were investigated in their microhabitat of different percent coverage of seagrasses. Water quality parameters in that microhabitat directly or indirectly affected the lives of sea cucumber. The average value of water quality parameters was presented in Table 2. The average temperature was higher in rubble microhabitat $\left(30.80 \pm 0.83^{\circ} \mathrm{C}\right)$ and the lower was in denser seagrasses $\left(29.20 \pm 0.34^{\circ} \mathrm{C}\right)$ with the contrary value for salinity. The average of seawater $\mathrm{pH}$ was not different among the microhabitats, whilst the dissolved oxygen was in the range of 4.37-8.5 ppm.

According to their weight size class, the number of individuals $(\%)$ found in different microhabitats were varied. The higher coverage of seagrass (P-1 and P-2) found to be occupied by smaller weight class of $H$. atra, i.e. weight less than 20 grams up to 60 grams (Table 3 ) and the larger size $H$. atra $(61->100$ grams) preferred in the more opened rubble microhabitat $(61.11 \%)$.

The samples of $H$. atra were weight according to their microhabitat and dissected the intestine were taken out and were weight (Table 4). It showed that the intestine weight was higher in the bigger sea cucumber, i.e. $61.11 \%$ above 61 grams of body weight in microhabitat of rubble (P-5). During sampling, the intestines of the $H$. atra were almost full of food, with the range of $64.60-80.38 \%$. To understand the selection of grain size by $H$. atra, the sediment and intestine digesta of $H$. atra were analyzed for their grain size and it showed that there was no clay in all microhabitat (Table 5).

Microhabitats with different coverage seagrasses revealed to have varied grain size characteristics. The relationship between sediment characteristics (i.e. grain size) of sampling station and digesta in alimentary canals of sea cucumber $H$. atra were analyzed to show the feeding activities of $H$. atra on sediment and were presented in Figure 3. Grain sizes of sediment underneath and in digesta of $H$. atra were connected in a linear equation. Grain size of sediment and in alimentary digesta had strong positive relation with correlation coefficient (p) range of 0.833 0.876 , and there was very strong relationship between them in station P-2 and P-4 with correlation coefficient range (p) of 0.945 (Figure 3).

The algal biomass in the seawater and sediment were assessed by measuring chlorophyll-a and the results were presented in Table 6. The naturally occurring organic content in marine sediments was measured as total organic matter (TOM). The concentration of chlorophyll-a and total organic matter in the seawater was lower than in sediment. The level of chlorophyll-a in the sediment expressed the concentration of microphytobenthic, which was the source of food for sea cucumber. The concentration of chlorophyll-a, Total organic matter (TOM), and food absorption (c) in the digesta of each part of the alimentary canal $H$. atra from all sampling stations as their microhabitat were measured and presented in Figure 4. 
Table 2. The water quality parameters of different microhabitats

\begin{tabular}{lccccc}
\hline \multirow{2}{*}{ Parameter } & \multicolumn{5}{c}{ Microhabitat } \\
\cline { 2 - 6 } & $\mathbf{P - 1}$ & $\mathbf{P - 2}$ & $\mathbf{P - 3}$ & $\mathbf{P - 4}$ & P-5 \\
\hline Temperature $\left({ }^{\circ} \mathrm{C}\right)$ & $29.20 \pm 0.34$ & $29.90 \pm 1.12$ & $30.20 \pm 0.08$ & $30.80 \pm 0.67$ & $30.80 \pm 0.83$ \\
Salinity $(\%$ oo & $31.00 \pm 0.78$ & $30.00 \pm 0.23$ & $30.20 \pm 0.43$ & $30.00 \pm 0.54$ & $29.00 \pm 0.34$ \\
pH & $7.56 \pm 0.21$ & $7.46 \pm 0.32$ & $7.52 \pm 0.22$ & $7.81 \pm 0.45$ & $7.53 \pm 0.22$ \\
Dissolved Oxygen $(\mathrm{ppm})$ & $6.90 \pm 1.40$ & $7.05 \pm 0.90$ & $7.90 \pm 0.67$ & $5.20 \pm 0.57$ & $4.60 \pm 0.23$ \\
Depth (m) & $3.00 \pm 0.30$ & $3.50 \pm 0.22$ & $5.00 \pm 0.20$ & $1.50 \pm 0.11$ & $0.62 \pm 0.10$ \\
\hline
\end{tabular}

Table 3. The percentage number individual (\%) of sea cucumber Holothuria atra found according to their weight size classes and microhabitats in Panjang Island

\begin{tabular}{cccccc}
\hline \multirow{2}{*}{ Weight class size (g) } & \multicolumn{5}{c}{ Number individual (\%) in microhabitat } \\
\cline { 2 - 6 } & P-1 & P-2 & P-3 & P-4 & P-5 \\
\hline 20 & 62.63 & 60.87 & 4.55 & 9.52 & - \\
$21-40$ & 26.32 & 39.13 & 86.36 & 66.67 & 16.67 \\
$41-60$ & 11.05 & - & 9.09 & 23.81 & 22.22 \\
$61-80$ & - & - & - & - & 44.44 \\
$81-100$ & - & - & - & - & 11.11 \\
$>100$ & - & - & - & 5.56 \\
\hline
\end{tabular}

Table 4. Total body weight (gr), intestine weight (gr) and intestine fullness (\%) of Holothuria atra from different microhabitats

\begin{tabular}{lccc}
\hline Station & $\begin{array}{c}\text { Total body weight }(\mathrm{g}) \\
\text { Average } \pm \text { SD }\end{array}$ & $\begin{array}{c}\text { Intestine weight }(\mathbf{g}) \\
\text { Average } \pm \text { SD }\end{array}$ & $\begin{array}{c}\text { Intestine fullness }(\%) \\
\text { Average } \pm \text { SD }\end{array}$ \\
\hline P-1 & $23.75 \pm 11.77$ & $18.78 \pm 11.02$ & $71.46 \pm 12.09$ \\
P-2 & $21.04 \pm 4.92$ & $18.02 \pm 5.21$ & $80.38 \pm 10.44$ \\
P-3 & $28.88 \pm 7.78$ & $26.20 \pm 10.22$ & $77.52 \pm 13.95$ \\
P-4 & $30.31 \pm 11.05$ & $26.97 \pm 13.99$ & $76.24 \pm 14.60$ \\
P-5 & $65.49 \pm 19.99$ & $41.47 \pm 10.05$ & $64.60 \pm 8.64$ \\
\hline
\end{tabular}

Table 5. The sediment characteristic of sampling station in Panjang Island, Jepara, Indonesia and intestine digesta (characteristic of Holothuria atra)

\begin{tabular}{|c|c|c|c|c|c|c|c|}
\hline \multirow[b]{2}{*}{ Station } & \multirow[b]{2}{*}{$\begin{array}{l}\text { Characteristic } \\
\text { of }\end{array}$} & \multirow[b]{2}{*}{$\begin{array}{l}\text { Number of } \\
\text { samples }\end{array}$} & \multicolumn{5}{|c|}{ Concentration (\%) } \\
\hline & & & Gravel & $\begin{array}{c}\text { Coarse } \\
\text { sand }\end{array}$ & $\begin{array}{l}\text { Fine } \\
\text { sand }\end{array}$ & Silt & Clay \\
\hline \multirow[t]{2}{*}{$\mathrm{P} 1$} & Sediment & 5 & 0 & 19.00 & 80.45 & 0.55 & 0 \\
\hline & Digesta & 5 & 0 & 41.41 & 54.06 & 4.53 & 0 \\
\hline \multirow[t]{2}{*}{$\mathrm{P} 2$} & Sediment & 5 & 2.10 & 15.80 & 77.30 & 4.80 & 0 \\
\hline & Digesta & 5 & 2.66 & 27.94 & 59.12 & 10.28 & 0 \\
\hline \multirow[t]{2}{*}{ P3 } & Sediment & 5 & 19.00 & 18.60 & 58.95 & 3.45 & 0 \\
\hline & Digesta & 5 & 0 & 38.31 & 57.06 & 4.63 & 0 \\
\hline \multirow[t]{2}{*}{ P4 } & Sediment & 5 & 7.60 & 38.20 & 53.90 & 0.30 & 0 \\
\hline & Digesta & 5 & 2.70 & 27.76 & 59.08 & 10.46 & 0 \\
\hline \multirow[t]{2}{*}{ P5 } & Sediment & 5 & 19.30 & 26.90 & 49.20 & 4.60 & 0 \\
\hline & Digesta & 5 & 35.50 & 24.11 & 35.04 & 5.35 & 0 \\
\hline
\end{tabular}

Table 6. The concentration of chlorophyll-a and total organic matter (TOM) in the seawater ( $\left.\mu \mathrm{g} . \mathrm{L}^{-1}\right)$ and sediment (mg. $\left.\mathrm{g}^{-1}\right)$ of each microhabitat of Panjang Island, Jepara

\begin{tabular}{ccccc}
\hline \multirow{2}{*}{ Micro-habitat } & \multicolumn{2}{c}{ Chlorophyll-a } & \multicolumn{2}{c}{ Total organic matter (TOM) } \\
\cline { 2 - 5 } & $\begin{array}{l}\text { Seawater }\left(\boldsymbol{\mu g} . \mathbf{L}^{-\mathbf{1}}\right)(\mathbf{n}=\mathbf{5}) \\
\text { Average } \pm \text { SD }\end{array}$ & $\begin{array}{l}\text { Sediment }\left(\boldsymbol{\mu g . g ^ { - 1 }}\right)(\mathbf{n}=\mathbf{5}) \\
\text { Average } \pm \text { SD }\end{array}$ & $\begin{array}{l}\text { Seawater }(\boldsymbol{\%})(\mathbf{n}=\mathbf{5}) \\
\text { Average } \pm \text { SD }\end{array}$ & $\begin{array}{l}\text { Sediment }(\%)(\mathbf{n}=5) \\
\text { Average } \pm \text { SD }\end{array}$ \\
\hline P-1 & $1.78 \pm 0.23$ & $143 \pm 2.45$ & $3.91 \pm 0.88$ & $32.11 \pm 2.22$ \\
P-2 & $0.89 \pm 0.12$ & $102 \pm 1.56$ & $5.47 \pm 0.12$ & $28.90 \pm 2.31$ \\
P-3 & $1.34 \pm 0,13$ & $20 \pm 1.11$ & $4.34 \pm 0.23$ & $28.57 \pm 1.11$ \\
P-4 & $2.23 \pm 0.24$ & $184 \pm 3.24$ & $4.79 \pm 0.09$ & $28.72 \pm 2.10$ \\
P-5 & $0.89 \pm 0.09$ & $409 \pm 4.44$ & $3.89 \pm 0.12$ & $29.27 \pm 2.11$ \\
\hline
\end{tabular}




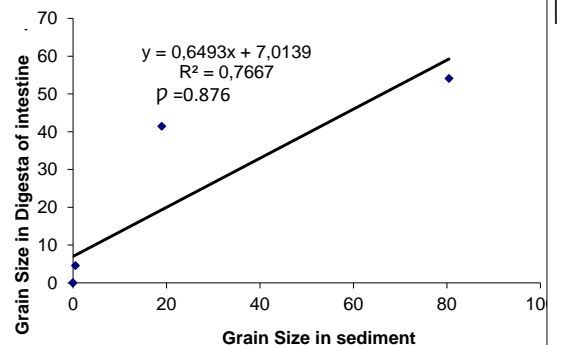

A

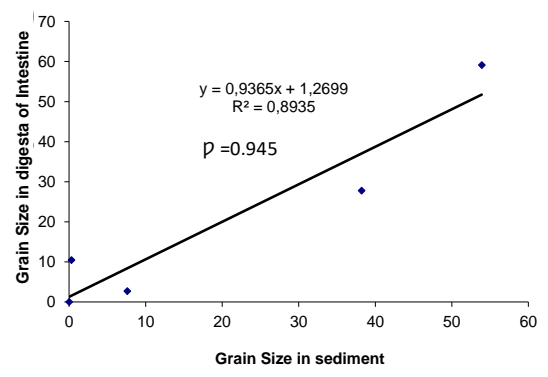

D

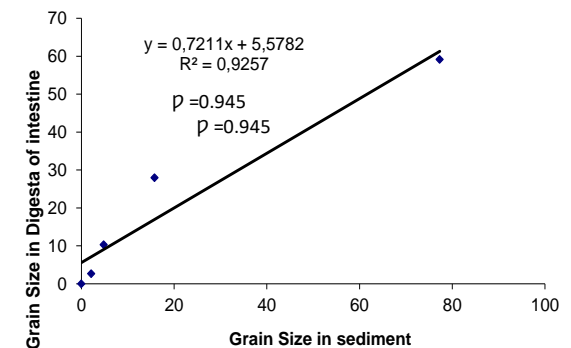

B

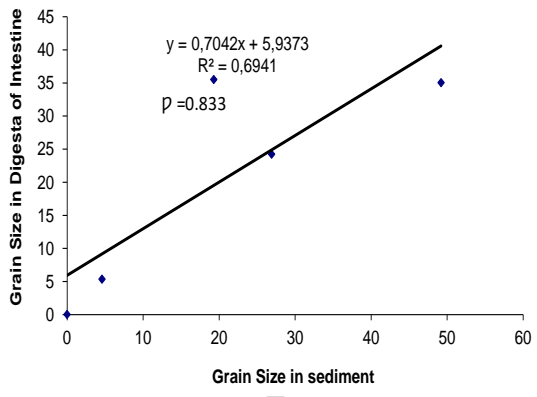

$\mathbf{E}$

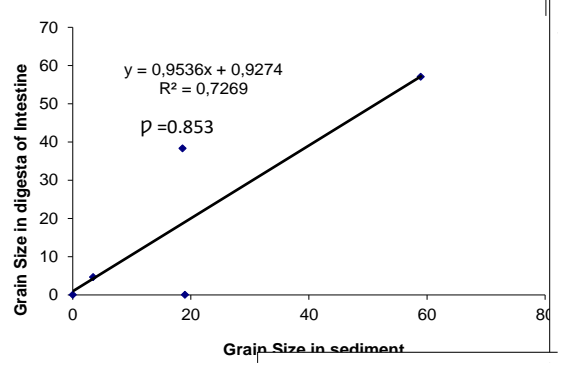

C

Figure 3. Relation between sediment characteristic (grain size) of sediment in different microhabitat. A. P-1, B. P-2, C. P-3, D. P-4 and E. P-5 and in intestine digesta of sea cucumber Holothuria atra in Panjang Island, Jepara, Indonesia

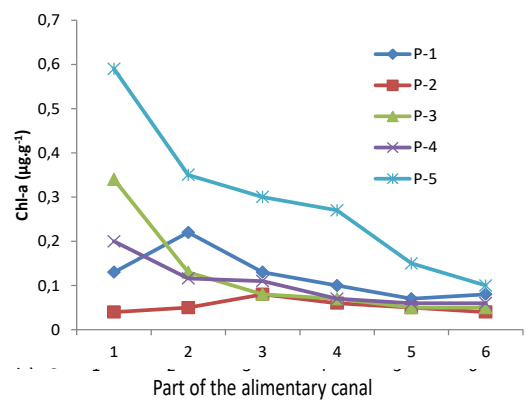

A

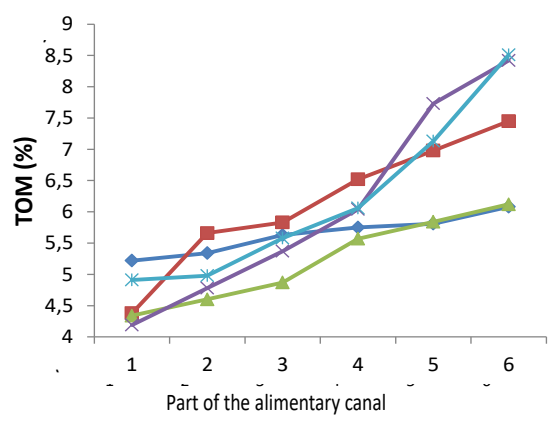

$\mathbf{B}$

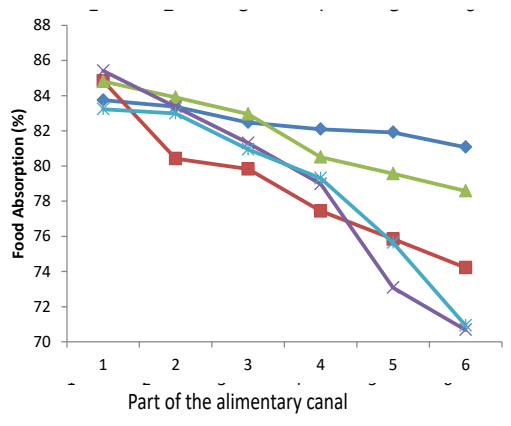

C

Figure 4. The concentration of chlorophyll-a (A), Total organic matter (TOM) (B) and food absorption (C) in the digesta of each part of the alimentary canal Holothuria atra from all sampling stations

\section{Discussion}

The sea cucumbers were found in variety of coverage of dominated seagrass species of $C$. serrulata. Although depending on the location, species of Cymodocea may be found associated with reefs and reef platforms but usually in intertidal regions (Setyastuti 2014; Wagey 2017). Tropical seagrasses occupied a variety of coastal habitats and they have typically occurred in most shallow, sheltered soft-bottomed marine coastlines and estuaries. The habitat complexity within seagrass meadows enhanced the diversity and abundance of animals. The water quality in this habitat was excellent and very close to ambient conditions for H. atra (Asha et al. 2015; Buccheri et al. 2019), with the range of temperature, salinity, $\mathrm{pH}$, dissolved oxygen was of $28.86-31.63^{\circ} \mathrm{C}, 28.66-31.78 \%$, 7.14-8.26 and 4.37-8.5ppm respectively. According to Dissanayake and Stefansson (2012), H. atra preferred shallow water less than $10 \mathrm{~m}$ depth and the depth of different microhabitats in this research were $0.62-5.0$ meters.

Microhabitat of $H$. atra in Panjang Island had different coverage of seagrasses. Seagrasses on reef flats and near estuaries acted as nutrient sinks, buffered or filtered nutrient and chemical inputs to the marine environment (Nordlund et al. 2017). The high primary production rates of seagrasses were closely linked to the high production rates of associated fisheries. One of seagrass associated epibenthic was H. atra (Setyastuti 2015). The present work revealed that the higher coverage of seagrass found to be occupied by smaller weight class of $H$. atra (Tables 1 and 2 ) and vice versa. Small size $H$. atra preferred to live under the taller seagrass stands, which could morphologically benefit for $H$. atra by providing better protection and shelter area (Hartati et al. 2017). In the rubble area where there was no seagrass, the bigger size of $H$. atra was found same as previous results of Hartati et al. (2019a,b). Table 3 
showed that the bigger size of $H$. atra live in a shallower area (Station P-4 and P-5 of 1.5 and 0.5-meter depth respectively) and located adjacent to the beach. For comparison, $23.29 \%$ of $H$. atra in Bama Beach, Baluran National Park in East Java were associated with $C$. rotundata (Setyastuti 2014).

Seagrasses acted as an indirect food source for benthic organisms like sea cucumber by which they might enter detrital food webs (Hartati et al. 2019a) after the seagrass decomposed (Liu et al. 2013). The highest average total body and intestine weight of $H$. atra was found in station P-5 (Tables 2 and 4). The bigger size of $H$. atra in Panjang Island commonly was found in the rubble area (Hartati et al. 2019b). Their feeding activity showed happened during the sampling, which could be seen from intestine fullness of 64.60-80.38\%. According to Ramon et al (2019), deposit-feeding animals such as sea cucumber acquired food by swallowing large volumes of sediment. It ingested sand grains, digested the nutrient, and then expelled sand pellets both in day and night time (Hartati et al. 2016). Possible food sources were included organic debris and sediment-associated microbes (i.e. microphytobenthos).

The evidence that $H$. atra fed on sediment underneath their body were presented in Tabel 5. Grain size regression between sediment and digesta of $H$. atra showed that there was very strong positive relationship between them in station P-2 and P-4 ( $p=0,945)$, and strong positive relationship in other stations $(p=0.833-0.876)$ (Figure 3$)$. According to Dissanayake and Stefansson (2012), in shallow water $(<10 \mathrm{~m})$ seagrass habitat with sediments characterized $15-25 \%$ of gravel and coarse sand (0.7$1.2 \mathrm{~mm}$ ) were the most preferred conditions by $H$. atra. The interesting results were in the rubble area (P-5) (Table 1 ), they accumulated gravel to get more microphytobenthic organisms as nutrient sources (Table 3 ). The size of $H$. atra in station P-5 was larger than other station (Table 2). Wang et al. (2010) and Sun et al. (2015) suggested that larger sized sea cucumbers had larger tentacles to collect food particles due to a larger capturing surface and a greater distance. The sea cucumbers picked up food particles from the sediment using the adhesive force and mechanical entrapment ability of the tentacles. The tentacles trapped particles and then took them into the mouth (Tehranifard and Rahimibashar 2012). Once inside the mouth the particles were compressed and transported by peristalsis, without further mixing, along with a simple tubular digestive system or alimentary canal (see Figure 2) that ended in the anus located in the posterior part of the animal (Hartati et al. 2016).

Deposit feeding sea cucumbers, such as $H$. atra, could only digest and utilize the organic component removed from the sediment (Lee et al. 2018). Typically the naturally occurring organic content in marine sediments, measured as total organic matter (TOM), was very low but it has not happened in Panjang Island (Table 5). Dissanayake and Stefansson (2012) examined the relationships between the density of $H$. atra and the habitat variables, such as mean grain size, organic content, amount of gravel and silt-mud contents, and depth using a generalized additive model showed that all these variables except silt-mud had a significant influence $(\mathrm{P}<0.05)$ on the habitat association of $H$. atra. Further, they found that $15-25 \%$ of gravel and coarse sand $(0.7-1.2 \mathrm{~mm})$ were the most preferred conditions by $H$. atra and organic content were significantly influence the habitat preference as nutrient source but not protection. The intake of nutrients from the organic component in the sediments was needed for sea cucumber growth and survival (Lee et al. 2018).

Chlorophyll-a in sediment could be representative of microphytobenthos (MPB), i.e. microalgae, cyanobacteria and other photosynthetic bacteria (Domínguez-Godino and González-Wangüemert 2020) which were important and crucial in coastal food webs because of their high accessibility to consumers, such as sea cucumber (Hartati et al. 2017) especially $H$. atra (Viyakarn et al. 2020). The high concentration of chlorophyll-a in the sediment (20$\left.409 \mu \mathrm{g} . \mathrm{g}^{-1}\right)$ was due to high abundance of microphytobenthic organisms. The measurement of the chlorophyll-a of digesta in alimentary canal of deposit feeder H. atra (Figure 4) showed the consumption of benthic microalgae taken from sediment. The digestion of them confirmed by decreasing the concentration of chlorophyll-a along the alimentary canal of sea cucumber.

Holothuria atra, as deposit-feeding sea cucumbers, digested and utilized organic component removed from the sediment (Viyakarn et al. 2020), as shown in digesta of their alimentary canal (Figure 4). As the concentration of TOM in sediment all station were almost the same, the selection behavior for organic carbon and nitrogen as shown by experiment of Schneider et al. (2013) could not be determined. The concentration of TOM in each part of alimentary canal of $H$. atra was similar to chlorophyll-a, which tends to be decreased from pharynx to cloaca. Once the ingested material entered the alimentary canal of sea cucumbers, it was mixed with digestive enzymes and compacted into a plug that moved throughout the gut following a plug-flow reactor model without radial and axial mixing of the sediment (Tolon et al. 2015). As this plug moved from mouth to anus, absorption of TOM was found to occur (Zamora and Jeffs 2011).

By comparing the TOM of digesta to that in the sediment, the absorption of TOM was found to occur all along the alimentary canal. Decreasing trend of TOM concentration in the digesta of the different sections of the sea cucumber's of present work (Figure 4) was similar to Zamora and Jeffs (2011) on Australostichopus mollis fed on different TOM. It found that under high concentration of TOM in the sediment, the absorptions in each part were the same efficient (70-85\%) along the alimentary canal. Under poor quality feeding conditions, as often encounter in the wild, a deposit feeder Australostichopus mollis greatly increased TOM selection and intake (Zamora and Jeffs 2011), but this did not happen in the present study. As the TOM of the sediment were higher in all station, the intake of this TOM was thought to be the result of more active particle selection. This was helped by the presence of chemosensory receptors and/or the selection of smaller organic-rich particles which might be easier to capture and retained in the tentacles than bigger particles (Schneider et al 2013; Lee et al. 2018). This high value of absorption 
efficiency was similar to those detected in other sea cucumbers species feeding on sediments with a low content of organic matter (Robinson et al. 2013)

It could be concluded that $H$. atra fed on sediment underneath their body. The feeding selectivity of the sediment for $H$. atra was strong to very strongly related to sediment size in alimentary canal. $H$. atra showed their feeding efficiency to take advantage of the high TOM content and high abundance of microphytobenthic organisms (presented as chlorophyll-a) in their natural microhabitats.

\section{ACKNOWLEDGEMENTS}

This research was funded by research scheme of Other than APBN SUKMA FPIK Diponegoro University 2018 No. 1501-20/UN.7.5.10/LT/2018 and International Research Publication scheme of PNBP DIPA Universitas Diponegoro through Other than APBN DPA SUKPA Research and Community Services Universitas Diponegoro the budget year of 2019, therefore authors wish to thanks to Rector and Dean of Faculty Fisheries and Marine Science Diponegoro University. We extend our gratitude to Mustagpirin, Fabian PA, Elsha L, and Robertus TM during their assistance in the fieldwork.

\section{REFERENCES}

Asha PS, Diwakar K, Santhanavalli G, Manissery MK. 2015. Comparative distribution and habitat preference of the sea cucumber Holothuria atra Jaeger at protected and unprotected sites in Thoothukudi region of Gulf of Mannar, south-east coast of India. Indian J Fish 62 (1): 52-57

Buccheri E, Foellmer MW, Christensen BA, Langis P, Ritter S, Wolf E, Freeman AS. 2019. Variation in righting times of Holothuria atra, Stichopus chloronotus, and Holothuria edulis in response to increased seawater temperatures on Heron Reef in the Southern GBR. J Mar Biol 2019: 1-6. DOI: 10.1155/2019/6179705

De Jonge VN, De Boer WF, de Jong DJ, Brauer VS. 2012. Long-term mean annual microphytobenthos chlorophyll a variation correlated with air temperature. Mar Ecol Prog Ser 468: 43-56. DOI: 10.3354/meps09954

Dissanayake DCT, Stefansson G. 2012. Habitat preference of sea cucumbers: Holothuria atra and Holothuria edulis in the coastal waters of Sri Lanka. J Mar Biol Ass UK 92 (3): 581-590.

Domínguez-Godino JA and González-Wangüemert M. 2020. Habitat associations and seasonal abundance patterns of the sea cucumber Holothuria arguinensis at Ria Formosa coastal lagoon (South Portugal). Aquat Ecol 54: 337-354. DOI: 10.1007/s10452-020-09746-0

Hartati R, Widianingsih, Djunaedi A. 2016. Ultrastruktur alimentary canal teripang Holothuria scabra dan Holothuria atra (Echinodermata: Holothuroidea). Buletin Oseanografi Marina 5 (1): 86-96. [Indonesian]

Hartati R, Widianingsih, Trianto A, Zainuri M, Ambariyanto. 2017. The abundance of prospective natural food for sea cucumber Holothuria atra at Karimunjawa Island waters, Jepara, Indonesia. Biodiversitas 18 (3): 947-953.

Hartati R, Zainuri M, Widianingsih W, Ambariyanto A, Mustagpirin M, Ayodya FP, Soegianto A. 2019a. Initial assessment of Holothuria atra in Panjang Island, Jepara, Indonesia. Ecol Environ Conserv 25: S1-S6. http://www.envirobiotechjournals.com/issue_articles.php?iid $=276 \&$ jid $=3$

Hartati R, Zainuri M, Ambariyanto A, Redjeki S, Riniatsih I, Azizah, RTN, Endrawati H. 2019b. Asexual Reproduction of Black sea cucumber from Jepara Waters. Ilmu Kelautan: Indonesian J Marine Sciences 24 (3): 121-126. DOI: 10.14710/ik.ijms.24.3.121-126.

Kashio S, Yamana Y, Furukawa N, Ekusa RU, and Goshima S. 2016. Seasonal microhabitat use patterns in Japanese sea cucumber Apostichopus japonicas in Funka Bay, Hokkaido, northern Japan. Aquacult Sci 64 (4): 371-378. DOI: 10.11233/aquaculturesci.64.371

Kusumadewi N, Hartati R. 2003. Food absorption in alimentary canal of Black sea cucumber (Holothuria atra). Jurnal Perikanan dan Ilmu Kelautan 3 (12): 87-95. [Indonesian]

Lee S, Ford AM, Mangubhai S, Wild C, Ferse SCA. 2018. Effects of sandfish (Holothuria scabra) removal on shallow-water sediments in Fiji. PeerJ 6: e4773; DOI 10.7717/peer

Liu X, Zhou Y, Yang H, Ru S. 2013. Eelgrass detritus as a food source for the sea cucumber Apostichopus japonicus Selenka (Echinodermata: Holothuroidea) in Coastal Waters of North China: An experimental study in flow-through systems. PLoS ONE 8 (3): e58293. DOI: 10.1371/journal.pone.0058293

Navarro PG, Garci'a-Sanz S, Barrio JM, Tuya F. 2013. Feeding and movement patterns of the sea cucumber Holothuria sanctori. Mar Biol 160: 2957-2966.

Nordlund LM, Koch EW， Barbier EB， Creed JC. 2017. Seagrass Ecosystem Services and Their Variability across Genera and Geographical Regions. PLoS ONE 12 (1): e0169942. https://doi.org/10.1371/journal.pone.0169942

Ramón M, Simarro G, Galimany E, Lleonart J. 2019. Evaluation of sediment particle size selection during feeding by the holothurian Parastichopus regalis (Cuvier, 1817). Regional Studies in Marine Science 31: 100763. DOI: 10.1016/j.rsma.2019.100763

Robinson G,. Slater MJ, Jones CLW, Stead SM. 2013. Role of sand as substrate and dietary component for juvenile sea cucumber Holothuria scabra. Aquaculture 392-395: 23-25

Sauchyn LK, Lauzon-Guay JS, Scheibling RE. 2011. Sea urchin fecal production and accumulation in a rocky subtidal ecosystem. Aquat Biol 13: 215-223.

Schneider K, Silverman J, Kravitz B, Rivlin T, Schneider-Mor A, Barbosa S, Maria Byrne M, Ken Caldeira K. 2013. Inorganic carbon turnover caused by digestion of carbonate sands and metabolic activity of holothurians. Estuar Coast Shelf Sci 133: 217-223

Setyastuti A. 2014. Echinodermata, Holothuria atra, in an intertidal seagrass bed off the Bama Beach, Baluran National Park, East Java, Indonesia. Jurnal Ilmu dan Teknologi Kelautan Tropis 6 (1): 31-39.

Setyastuti A. 2015. The occurrence and distribution of two black sea cucumber species in Pombo Island, Central Maluku (Indonesia). Mar Res Indon 40 (2): 49-63.

Sun J, Zhang L, Pana Y, Lin C, Wang F, Kand R, Yang H. 2015. Feeding behavior and digestive physiology in sea cucumber Apostichopus japonicus. Physiol Behav 139: 336-343.

Tehranifard A, Rahimibashar MR. 2012. Description of a sea cucumber species Holothuria atra Jaeger, 1833 from Kish Island Iran (Echinodermata: Holothuroidea). J Basic Appl Sci Res 2 (12): 1266012664.

Tolon T, Emiroglu D, Günay D, Saygi H. 2015. Effect of sediment grain size on growth performance of juvenile sea cucumber (Holothuria tubulosa). Turk J Fish Aquat Sci 15: 561-565. DOI: 10.4194/13032712-v15_2_43

Viyakarn V, Chavanich S, Heery E, Raksasab C. 2020. Distribution of sea cucumbers, Holothuria atra, on reefs in the upper Gulf of Thailand and the effect of their population densities on sediment microalgal productivity. Estuar Coast Shelf Sci 235: 106514 DOI: 10.1016/j.ecss.2019.106514

Wagey BT. 2017. Morphometric analysis of congeneric seagrasses (Cymodocea rotundata and Cymodocea serrulata) in the coastal areas of Bunaken National Park, North Sulawesi, Indonesia. AACL Bioflux 10 (6): 1638-1646.

Wang J, Cong W, Jiang Y, Zhang J. 2010. Effects benthic diatom species and density on settlement and ontogenetic development of feeding organs in sea cucumber Apostichopus japonicus. J Dalian Ocean Univ 4: 298-307 [Chinese].

Wang Q, Li Y, Wang Y. 2011. Optimizing the weight loss-on-ignition methodology to quantify organic and carbonate carbon of sediments from diverse sources. Environ Monit Assess 174: 241-257.

Zamora LN, Jeffs AG. 2011. Feeding, selection, digestion and absorption of the organic matter from mussel waste by juveniles of the depositfeeding sea cucumber, Australostichopus mollis. Aquaculture 317: 223-228. 